\title{
Assessment of Water and Proppant Quantities Associated with Petroleum Production from the Eagle Ford Group, Gulf Coast, Texas, 2019
}

Building on a geology-based assessment of undiscovered, technically recoverable petroleum resources in the Eagle Ford Group in south Texas, the U.S. Geological Survey has estimated the required water and proppant demands and formation water production volumes associated with possible future development of these petroleum resources. The results of the water and proppant assessment are presented here, along with related drilling information and relevant water budget volumes for the region.

\section{Introduction}

The U.S. Geological Survey (USGS) has completed an assessment of water and proppant requirements and formation water production associated with the possible future production of undiscovered oil and gas resources in the Cenomanian-Turonian Eagle Ford Group in south Texas (fig. 1). This water and proppant assessment is directly linked to the geology-based assessment of the undiscovered, technically recoverable continuous oil and gas resources described by Whidden and others (2018).

The production of oil and gas from continuous (unconventional) accumulations, such as those in the Eagle Ford Group, is made possible by hydraulic fracturing stimulation, which involves pumping high volumes of fluid containing water and proppant (primarily sand) into the petroleum reservoir to hold open the newly created fractures and improve fluid-flow characteristics. Water is also a key component of drilling mud and may be lost to the surrounding formations during the drilling process, and water is required to cement the well casing in place.

During petroleum production, wastewater from the formation is generally produced along with oil and gas. This produced water includes hydraulic fracturing water, which returns as flowback water early in the life of the well, and formation water, which is produced throughout the duration of petroleum production. In this study, flowback water was not assessed because of a lack of necessary data, and therefore, only an assessment of the contribution of formation water to the total produced water is presented.

\section{Assessment Approach and Input Values}

The USGS methodology for assessing water and proppant requirements and water production associated with possible future production of oil and gas from continuous accumulations is described by Haines (2015). The methodology incorporates many elements of the USGS approach for assessing continuous petroleum accumulations (Charpentier and Cook, 2010), including estimated ultimate recovery (EUR) of petroleum per well and the input values and calculations for estimating the number of wells potentially associated with production of the petroleum in each assessment unit (AU). In addition, the water and proppant assessment methodology includes input values for the water per well for drilling and cement and for hydraulic fracturing treatment, along with proppant-to-water ratio for hydraulic fracturing, and long-term, water-to-oil or water-to-gas ratios. The long-term produced water-to-petroleum ratio represents formation water (that is, the water that exists with petroleum in the geologic formation). A Monte Carlo approach provides probabilistic outputs based on distributions of input parameters (Haines, 2015).

This water and proppant assessment for the Eagle Ford Group incorporates the geologic information in the 2018 assessment of oil and gas (Whidden and others, 2018), and it uses the same values for EUR and inputs that are part of the well-count calculation. In

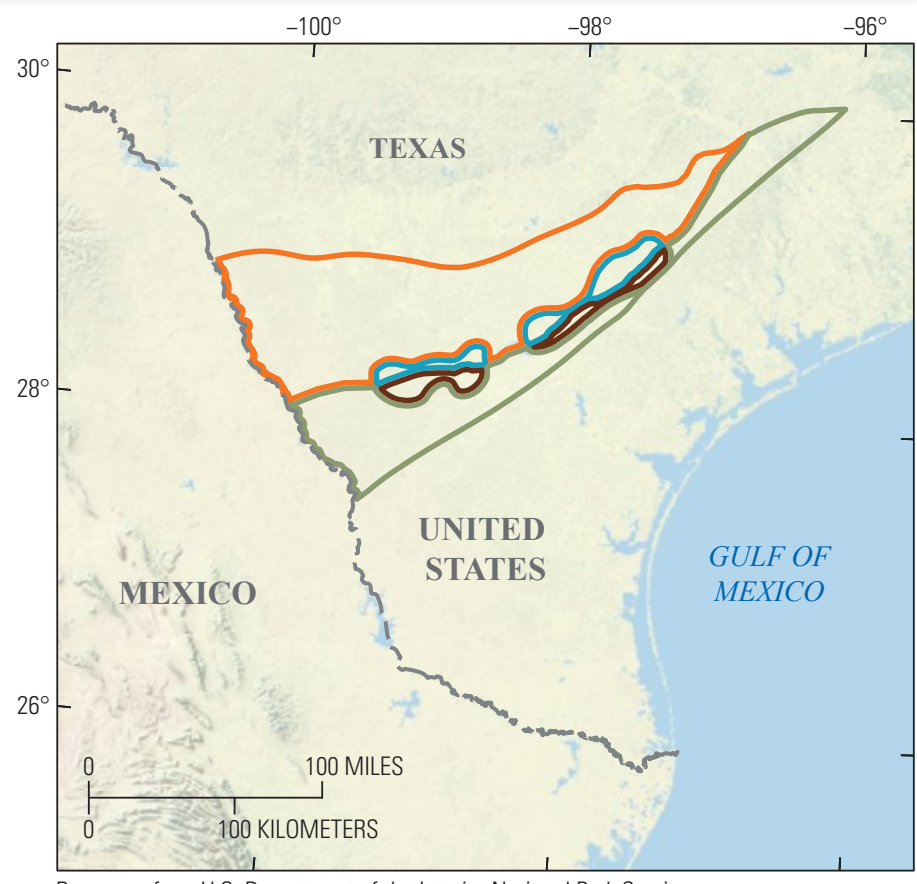

Base map from U.S. Department of the Interior National Park Service

EXPLANATION

Eagle Ford Marl Continuous Oil AU

Submarine Plateau-Karnes Trough Continuous Oil AU

- Submarine Plateau-Karnes Trough Continuous Gas AU

Eagle Ford Marl Continuous Gas AU

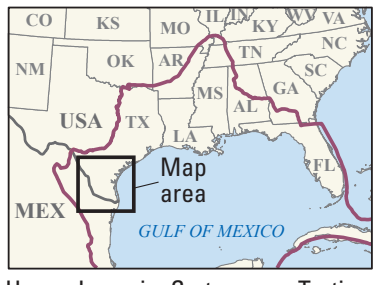

Upper Jurassic-Cretaceous-Tertiary Composite Total Petroleum System boundary (part) shown in plum.

Figure 1. Assessment units $(A U)$ in the Cenomanian-Turonian Eagle Ford Group in south Texas (Whidden and others, 2018).

the petroleum assessment, Whidden and others (2018) defined seven continuous AUs within the Eagle Ford Group that are part of the Jurassic-Cretaceous-Tertiary Composite Total Petroleum System (fig. 1). The petroleum assessment included three continuous Cenomanian-Turonian AUs that were not assessed as part of the water assessment because petroleum drilling in these areas has been minimal in recent years such that water- and proppant-related patterns are not yet evident from the sparse data.

Input values for this assessment were determined by analyzing water and proppant use and water production data for the Eagle Ford Group from IHS Markit ${ }^{\mathrm{TM}}$ (2018). All inputs are specified as ranges of possible mean values, rather than as single fixed values, to allow quantification of uncertainty throughout the assessment process. Selected assessment input values are shown in table 1. 
Table 1. Selected input values for the water and proppant assessment in the Eagle Ford Group, Gulf Coast Province, Texas.

[AU, assessment unit; Mgal, million gallons; lb/gal, pound per gallon; \%, percent; bbl, barrel; mcf, thousand cubic feet]

\begin{tabular}{|c|c|c|c|c|}
\hline Assessment input values common among all AUs & Minimum & Mode & Maximum & Calculated mean \\
\hline Water per well, for drilling and cement (Mgal) & 0.2 & 0.3 & 0.4 & 0.3 \\
\hline Water per well, for hydraulic fracturing treatment (Mgal) & 10.0 & 12.0 & 16.0 & $12 . \overline{6}$ \\
\hline Proppant-to-water ratio, for hydraulic fracturing (lb/gal) & 1.15 & 1.25 & 1.35 & 1.25 \\
\hline Fraction of hydraulic fracturing treatment volume that returns as flowback water (\%) & \multicolumn{4}{|c|}{ Insufficient data to determine } \\
\hline Assessment units (AUs) of the Eagle Ford Group & Minimum & Mode & Maximum & Calculated mean \\
\hline \multicolumn{5}{|c|}{ Long-term produced water ratio inputs specified separately for each AU (bbl water per bbl oil; gal water per mcf gas) } \\
\hline Eagle Ford Marl Continuous Oil AU & 0.3 & 0.6 & 0.9 & 0.6 \\
\hline Submarine Plateau-Karnes Trough Continuous Oil AU & 0.13 & 0.20 & 0.30 & 0.21 \\
\hline Submarine Plateau-Karnes Trough Continuous Gas AU & 0.63 & 1.05 & 1.47 & 1.05 \\
\hline Eagle Ford Marl Continuous Gas AU & 0.42 & 1.05 & 1.68 & 1.05 \\
\hline
\end{tabular}

While some assessment inputs are driven by technical choices made by oil and gas production companies, other inputs are directly related to geologic characteristics of the formation. Inputs related to technical choices were assigned the same values for all AUs based on the observation that similar hydraulic fracturing technologies are being employed throughout the entire assessment area. The differences in the data correspond with differences between operators and not to any identifiable geologic trends. Based on analysis of water use for hydraulic fracturing of wells producing from the Eagle Ford Group (IHS Markit ${ }^{\mathrm{TM}}$, 2018), the water requirement for hydraulic fracturing treatment was estimated as a range, with a mean value of $12 . \overline{6}$ million gallons per well. From the same data source, the mean value of the proppant-to-water ratio for hydraulic fracturing treatments was estimated to be 1.25 pounds of proppant per gallon of water (lbs/gal). Based on trends reported for similar wells and on volumetric estimates for the Eagle Ford Group wells, the mean value of the water requirement per well for drilling and cement was estimated to be 300,000 gallons.

In the State of Texas, well-by-well water production from oil and gas wells is not reported on a monthly basis because such reporting is not required by law as in some other States. Alternatively, we used production test data (IHS Markit ${ }^{\mathrm{TM}}, 2018$ ), that are reported less frequently, generally every 6 months. This difference in type and frequency of data used in our analysis is significant because the data for the Eagle Ford Group are temporally much more sparse than in locations such as the Williston Basin, where States require monthly reporting of water quantities associated with oil and gas production (Haines and others, 2017). The water and proppant assessment methodology (Haines, 2015) describes the estimation of two different input values: (1) the percent of hydraulic fracturing fluid that returns to the surface as flowback water and (2) the long-term water-to-oil ratio for production over the life of the well. In this study, assessing flowback water is not possible because of the lack of monthly water data. On the basis of spatial and temporal analysis of available data for wells producing from the Eagle Ford Group, the long-term, water-to-petroleum ratio was specified uniquely for each AU.

\section{Results of Water and Proppant Assessment and Supporting Information}

Results from the 2019 USGS water and proppant assessment are shown in table 2. All assessment outputs are distributions that indicate the range of possible values, which are summarized in the table with the 95th fractile (F95); 50th fractile, or median (F50); 5th fractile (F5); and the mean value.

Summing over the four AUs of the Eagle Ford Group assessed, the mean estimated total volume of water that would be required for drilling and cement is 15.8 billion gallons, the mean estimated volume of water required for hydraulic fracturing is 671.8 billion gallons, the mean estimated quantity of proppant for hydraulic fracturing is 420 million tons, and the mean estimated total volume of formation water is 177 billion gallons.

The assessment outputs shown in table 2 are estimates of the total water and proppant requirements and total water production associated with development of the entire undiscovered petroleum resource in the four Eagle Ford Group AUs (Whidden and others, 2018). Any future extraction of this oil resource will take place at a rate and timing that are unknown and a totality that is uncertain. Additional information intended to highlight questions involving the rate of oil development on an annual basis is presented in tables 3 and 4. Specifically, the tables show the reported number of oil and gas wells drilled annually within each AU from 2013 to 2017 (table 3; IHS Markit ${ }^{\mathrm{TM}}$, 2018), and estimated quantities of water and proppant associated with different scenarios for possible drilling rates (table 4). These water and proppant volume estimates are based on the mean values of the associated assessment input distributions. Formation water production is not shown in table 3 because annual water production for any given year is dependent on the number of producing wells drilled in previous years.

To provide additional context for the water volumes shown in tables 2, 3, and 4, table 5 shows water quantities for other parts of the hydrologic system within the area of each AU. These include the total water produced as part of all oil and gas production within the map area of the AU (IHS Markit ${ }^{\mathrm{TM}}, 2018$ ), total surface water and groundwater withdrawals (Dieter and others, 2018), and water use in four categories: (1) agriculture (including use for irrigation, livestock, and aquaculture), (2) industrial (including mining and self-supplied industrial use), (3) municipal (public supply and self-supplied domestic use), and (4) thermoelectric power plants (Dieter and others, 2018). Each of these volumes is the total production, withdrawal, or use of water within the map area of each AU.

Additional information to facilitate comparison between the four AUs of the Eagle Ford Group and the USGS water and proppant assessment for the Bakken and Three Forks Formations in the Williston Basin (Haines and others, 2017) is included in tables 6 and 7 . The tables summarize the estimated water and proppant requirements, and total produced water production, per barrel of undiscovered, technically recoverable oil (table 6) or per billion cubic feet of undiscovered, technically recoverable gas (table 7) in each AU. Each of these estimates is based on the mean value of the relevant distributions. For completeness, the mean value of the estimated undiscovered oil or gas resources in each AU (Whidden and others, 2018) is also shown.

\section{For More Information}

Assessment results are available at the USGS Energy Resources Program website at https://energy.usgs.gov. 
Table 2. Assessment results showing resource requirements and formation water associated with production of continuous petroleum deposits in the Eagle Ford Group, Gulf Coast Province, Texas.

[F95 represents a 95-percent chance of at least the amount tabulated; other fractiles are defined similarly. Gray shading indicates not applicable. Mgal, million gallons]

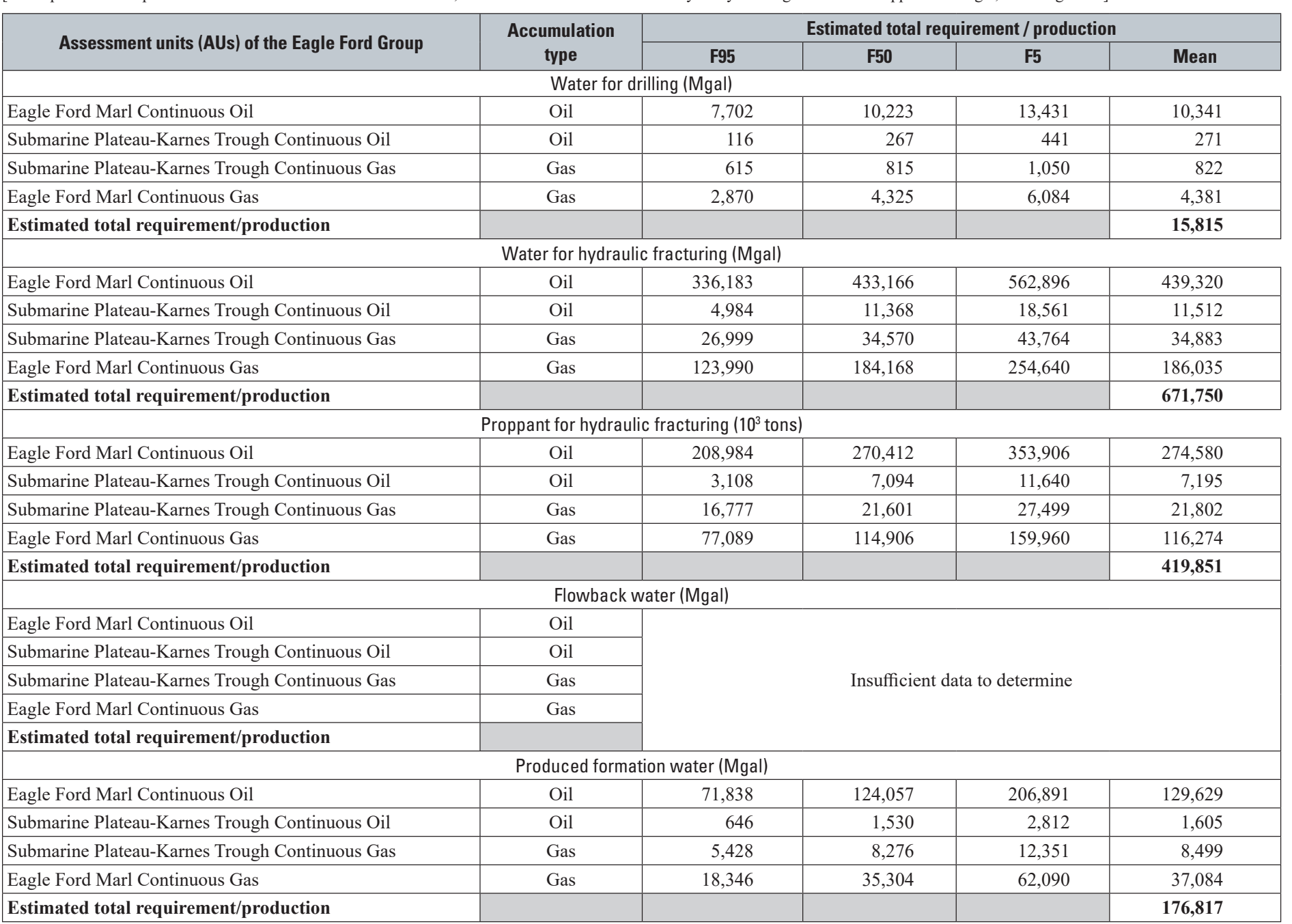

Table 3. Historical number of wells drilled in each assessment unit (AU) in the Eagle Ford Group, Gulf Coast Province, Texas during each of the indicated years.

[Gray shading indicates not applicable. Mgal, million gallons]

\begin{tabular}{|c|c|c|c|c|c|c|c|c|}
\hline \multirow{3}{*}{$\begin{array}{l}\text { Assessment units (AUs) of the } \\
\text { Eagle Ford Group }\end{array}$} & \multirow{3}{*}{$\begin{array}{l}\text { Accumu- } \\
\text { lation } \\
\text { type }\end{array}$} & \multicolumn{5}{|c|}{$\begin{array}{c}\text { Historical drilling' } \\
\text { (number of wells drilled each year) }\end{array}$} & \multirow{2}{*}{\multicolumn{2}{|c|}{$\begin{array}{c}\text { Corequirements and coproduction } \\
\text { for several hypothetical annual } \\
\text { drilling totals }\end{array}$}} \\
\hline & & & & & & & & \\
\hline & & 2013 & 2014 & 2015 & 2016 & 2017 & $\begin{array}{l}\text { Total required } \\
\text { water (Mgal) }\end{array}$ & $\begin{array}{l}\text { Require proppant } \\
\text { (10 } 10^{3} \text { tons) }\end{array}$ \\
\hline Eagle Ford Marl Continuous Oil & Oil & 2,860 & 3,145 & 1,998 & 1,090 & 1,038 & 130 & 79 \\
\hline Submarine Plateau-Karnes Trough Continuous Oil & Oil & 523 & 704 & 660 & 227 & 236 & 130 & 79 \\
\hline Submarine Plateau-Karnes Trough Continuous Gas & Gas & 75 & 24 & 46 & 10 & 8 & 130 & 79 \\
\hline Eagle Ford Marl Continuous Gas & Gas & 179 & 191 & 120 & 105 & 132 & 130 & 79 \\
\hline Total & & 3,637 & 4,064 & 2,824 & 1,432 & 1,414 & & \\
\hline
\end{tabular}

${ }^{1}$ From IHS Markit ${ }^{\mathrm{TM}}$ (2018).

Table 4. Quantities of water and proppant use and water production potentially associated with several hypothetical future annual drilling rates.

\begin{tabular}{|c|c|c|c|c|c|c|}
\hline \multirow{3}{*}{$\begin{array}{l}\text { Assessment units (AUs) of the } \\
\text { Eagle Ford Group }\end{array}$} & \multicolumn{6}{|c|}{ Corequirements and coproduction for several hypothetical annual drilling totals } \\
\hline & \multicolumn{2}{|c|}{100 wells } & \multicolumn{2}{|c|}{1,000 wells } & \multicolumn{2}{|c|}{5,000 wells } \\
\hline & $\begin{array}{c}\text { Required } \\
\text { water } \\
\text { (Mgal) }\end{array}$ & $\begin{array}{l}\text { Required } \\
\text { proppant } \\
\text { (10 } 10^{3} \text { tons) }\end{array}$ & $\begin{array}{c}\text { Required } \\
\text { water } \\
\text { (Mgal) }\end{array}$ & $\begin{array}{l}\text { Required } \\
\text { proppant } \\
\text { (103 tons) }\end{array}$ & $\begin{array}{c}\text { Required } \\
\text { water } \\
\text { (Mgal) }\end{array}$ & $\begin{array}{l}\text { Required } \\
\text { proppant } \\
\text { (10 } 0^{3} \text { tons) }\end{array}$ \\
\hline Eagle Ford Marl Continuous Oil & 1,297 & 792 & 12,967 & 7,917 & 64,833 & 39,583 \\
\hline Submarine Plateau-Karnes Trough Continuous Oil & 1,297 & 792 & 12,967 & 7,917 & 64,833 & 39,583 \\
\hline Submarine Plateau-Karnes Trough Continuous Gas & 1,297 & 792 & 12,967 & 7,917 & 64,833 & 39,583 \\
\hline Eagle Ford Marl Continuous Gas & 1,297 & 792 & 12,967 & 7,917 & 64,833 & 39,583 \\
\hline
\end{tabular}


Table 5. Water quantities produced, withdrawn, and used for various purposes within each assessment unit (AU) in the Eagle Ford Group, Gulf Coast Province, Texas. [Mgal, million gallons]

\begin{tabular}{|c|c|c|c|c|c|c|c|}
\hline \multirow{2}{*}{$\begin{array}{c}\text { Assessment units (AUs) of the Eagle } \\
\text { Ford Group }\end{array}$} & \multirow{2}{*}{\begin{tabular}{|} 
Oil/gas total produced water ${ }^{1}$ \\
(mean annual production, \\
2013-2017, total for all producing \\
formations within AU map area) \\
(Mgal)
\end{tabular}} & \multirow{2}{*}{\begin{tabular}{|c|} 
Surface water $^{2}$ \\
Withdrawal \\
(annual total, \\
2015) (Mgal)
\end{tabular}} & \multirow{2}{*}{$\begin{array}{l}\text { Groundwater }^{2} \\
\text { Withdrawal } \\
\text { (annual total, } \\
\text { 2015) (Mgal) }\end{array}$} & \multicolumn{4}{|c|}{$\begin{array}{c}\text { Water use }^{2} \\
\text { (annual total, 2015) }\end{array}$} \\
\hline & & & & $\begin{array}{l}\text { Agriculture } \\
\text { (Mgal) }\end{array}$ & $\begin{array}{l}\text { Industrial } \\
\text { (Mgal) }\end{array}$ & $\begin{array}{l}\text { Municipal } \\
\text { (Mgal) }\end{array}$ & $\begin{array}{l}\text { Thermo- } \\
\text { electric } \\
\text { (Mgal) }\end{array}$ \\
\hline Eagle Ford Marl Continuous Oil & 10,046 & 15,262 & 63,850 & 44,527 & 15,853 & 16,978 & 1,753 \\
\hline $\begin{array}{l}\text { Submarine Plateau-Karnes Trough } \\
\text { Continuous Oil }\end{array}$ & 1,160 & 395 & 3,314 & 447 & 2,532 & 723 & 7 \\
\hline $\begin{array}{l}\text { Submarine Plateau-Karnes Trough } \\
\text { Continuous Gas }\end{array}$ & 264 & 244 & 2,674 & 350 & 2,087 & 481 & 0 \\
\hline Eagle Ford Marl Continuous Gas & 1,704 & 18,458 & 11,184 & 10,409 & 5,401 & 9,502 & 4,330 \\
\hline
\end{tabular}

${ }^{1}$ From IHS Markit ${ }^{\mathrm{TM}}(2018)$.

${ }^{2}$ From Dieter and others (2018)

Table 6. Water demand, proppant demand, and water production per unit of undiscovered, technically recoverable oil based on mean values of the assessment outputs in the Eagle Ford Group, Gulf Coast Province, Texas. The bottom row of this table shows the mean value across both oil assessment units, weighted by the volume of undiscovered, technically recoverable oil.

[Gray shading indicates not applicable. mmbo, million barrels of oil; Mgal, million gallons]

\begin{tabular}{|c|c|c|c|c|c|c|}
\hline \multirow{2}{*}{$\begin{array}{l}\text { Assessment units (AUs) of the Eagle } \\
\text { Ford Group }\end{array}$} & \multirow{2}{*}{$\begin{array}{c}\text { Predominant } \\
\text { accumulation } \\
\text { type }\end{array}$} & $\begin{array}{c}\text { Total } \\
\text { undiscovered } \\
\text { oil' (mmbo) }\end{array}$ & $\begin{array}{c}\text { Water requirement } \\
\text { per oil } \\
\text { (Mgal/mmbo) }\end{array}$ & $\begin{array}{c}\text { Proppant requirement } \\
\text { per oil } \\
\left(10^{3} \text { tons } / \mathrm{mmbo}\right)\end{array}$ & $\begin{array}{l}\text { Flowback water } \\
\text { production per oil } \\
\text { (Mgal/mmbo) }\end{array}$ & $\begin{array}{l}\text { Total formation } \\
\text { water per oil } \\
\text { (Mgal/mmbo) }\end{array}$ \\
\hline & & Mean & Mean & Mean & Mean & Mean \\
\hline Eagle Ford Marl Continuous Oil & Oil & 5,129 & 87.7 & 53.5 & Insufficient data & 25.27 \\
\hline $\begin{array}{l}\text { Submarine Plateau-Karnes Trough } \\
\text { Continuous Oil }\end{array}$ & Oil & 182 & 64.7 & 39.5 & Insufficient data & 8.82 \\
\hline Weighted mean & & & 86.9 & 53.1 & Insufficient data & 24.70 \\
\hline
\end{tabular}

${ }^{1}$ From Whidden and others (2018).

Table 7. Water demand, proppant demand, and water production per unit of undiscovered, technically recoverable gas based on mean values of the assessment outputs in the Eagle Ford Group, Gulf Coast Province, Texas. The bottom row of this table shows the mean value across both gas assessment units, weighted by the volume of undiscovered, technically recoverable gas.

[Gray shading indicates not applicable. bcfg, billion cubic feet of gas; Mgal, million gallons]

\begin{tabular}{|c|c|c|c|c|c|c|}
\hline \multirow[t]{2}{*}{$\begin{array}{l}\text { Assessment units (AUs) of the Eagle } \\
\text { Ford Group }\end{array}$} & \multirow[t]{2}{*}{$\begin{array}{l}\text { Predominant } \\
\text { accumulation } \\
\text { type }\end{array}$} & \begin{tabular}{|c|}
$\begin{array}{c}\text { Total undiscovered } \\
\text { gas }^{1} \\
\text { (bcfg) }\end{array}$ \\
\end{tabular} & $\begin{array}{c}\text { Water requirement } \\
\text { per gas } \\
\text { (Mgal/bcfg) }\end{array}$ & $\begin{array}{l}\text { Proppant require- } \\
\text { ment per gas } \\
\left(10^{3} \text { tons/bcfg) }\right.\end{array}$ & $\begin{array}{c}\text { Flowback water } \\
\text { production per gas } \\
\text { (Mgal/bcfg) }\end{array}$ & $\begin{array}{c}\text { Total formation } \\
\text { water per gas } \\
\text { (Mgal/bcfg) }\end{array}$ \\
\hline & & Mean & Mean & Mean & Mean & Mean \\
\hline $\begin{array}{l}\text { Submarine Plateau-Karnes Trough } \\
\text { Continuous Gas }\end{array}$ & Gas & 8,100 & 4.41 & 2.7 & Insufficient data & 1.05 \\
\hline Eagle Ford Marl Continuous Gas & Gas & 35,304 & 5.39 & 3.3 & Insufficient data & 1.05 \\
\hline Weighted mean & & & 5.21 & 3.2 & Insufficient data & 1.05 \\
\hline
\end{tabular}

${ }^{1}$ From Whidden and others (2018).

\section{Acknowledgments}

The authors thank Michael Brownfield (USGS) and Josh Valder (USGS) for peer reviews, and Jeremy McDowell (USGS Texas Water Science Center) for discussion providing insight into hydraulic fracturing practices in the region.

\section{References Cited}

Charpentier, R.R., and Cook, T.A., 2010, Improved USGS methodology for assessing continuous petroleum resources (ver. 2.0, November 9, 2012): U.S. Geological Survey Data Series 547, 22 p. and program, accessed May 31, 2017, at https://pubs.usgs.gov/ds/547.

Dieter, C.A., Linsey, K.S., Caldwell, R.R., Harris, M.A., Ivahnenko, T.I., Lovelace, J.K., Maupin, M.A., and Barber, N.L., 2018, Estimated use of water in the United States county-level data for 2015 (ver. 2.0, June 2018): U.S. Geological Survey data release, accessed August 2019, at https://doi.org/10.5066/F7TB15V5/.

Haines, S.S., 2015, Methodology for assessing quantities of water and proppant injection, and water production associated with development of continuous petroleum accumulations:
U.S. Geological Survey Open-File Report 2015-1117, 18 p., accessed May 31, 2017, at https://doi.org/10.3133/ofr20151117.

Haines, S.S., Varela, B.A., Hawkins, S.J., Gianoutsos, N.J., Thamke, J.N., Engle, M.A., Tennyson, M.E., Schenk, C.J., Gaswirth, S.B., Marra, K.R., Kinney, S.A., Mercier, T.J., and Martinez, C.D., 2017, Assessment of water and proppant quantities associated with petroleum production from the Bakken and Three Forks Formations, Williston Basin Province, Montana and North Dakota, 2016: U.S. Geological Survey Fact Sheet 2017-3044, 4 p. [Also available at https://doi.org/10.3133/fs20173044.]

IHS Markit ${ }^{\mathrm{TM}}$, 2018, US Well History and Production Database: Englewood, Colo., IHS Markit ${ }^{\mathrm{TM}}$, accessed at http://www.ihsenergy.com. [Available from IHS Markit ${ }^{\mathrm{TM}}, 15$ Inverness Way East, Englewood, CO 80112.]

Whidden, K.J., Pitman, J.K., Pearson, O.N., Paxton, S.T., Kinney, S.A., Gianoutsos, N.J., Schenk, C.J., Leathers-Miller, H.M., Birdwell, J.E., Brownfield, M.E., Burke, L.A., Dubiel, R.F., French, K.L., Gaswirth, S.B., Haines, S.S., Le, P.A., Marra, K.R., Mercier, T.J., Tennyson, M.E., and Woodall, C.A., 2018, Assessment of undiscovered oil and gas resources in the Eagle Ford Group and associated Cenomanian-Turonian strata, U.S. Gulf Coast, Texas, 2018: U.S. Geological Survey Fact Sheet 2018-3033, 4 p. [Also available at https://doi.org/10.3133/fs20183033.]

\section{Eagle Ford Water and Proppant Assessment Team}

Nicholas J. Gianoutsos, Seth S. Haines, Brian A. Varela, Katherine J. Whidden, Justin E. Birdwell, Lauri A. Burke, Ronald M. Drake II, Thomas M. Finn, Katherine L. French, Karen E. Jenni, Scott A. Kinney, Phuong A. Le, Heidi M. Leathers-Miller, Kristen R. Marra, Tracey J. Mercier, Stanley T. Paxton, Janet K. Pitman, Christopher J. Schenk, Brian N. Shaffer, Chilisa M. Shorten, Marilyn E. Tennyson, and Cheryl A. Woodall 